\title{
Hypersensitivitet ved bruk av ikke-steroide antiinflammatoriske legemidler
}

\author{
Bruk av ikke-steroide antiinflammatoriske legemidler (NSAID) er en \\ hyppig årsak til uønskede legemiddelreaksjoner. Klinikere bør tilegne \\ seg tilstrekkelig kunnskap om mulige mekanismer og kliniske karakte- \\ ristiska ved hypersensitivitetsreaksjoner forårsaket av NSAID-preparater.
}

Se også kunnskapsprøve på www.tidsskriftet.no/quiz

\section{Fatemeh Chalabianloo}

fatemeh.chalabianloo@helse-bergen.no Laboratorium for klinisk biokjemi Seksjon for klinisk farmakologi og

Yrkesmedisinsk avdeling

Seksjon for klinisk spesialallergologi

Haukeland universitetssykehus

Hypersensitivitetsreaksjoner på legemidler er verken forutsigbare eller doseavhengige og utgjør opptil en tredel av alle uønskede reaksjoner på legemidler (1). Ikke-steroide antiinflammatoriske legemidler (NSAID) er etter betalaktamantibiotika den nest vanligste årsaken til legemiddelutløste hypersensitivitetsreaksjoner, også i Norge $(2,3)$. Noe av forklaringen på dette er at NSAID-preparater har utbredt indikasjon og brukes i alle aldersgrupper (2). Rundt 0,6-2,5\% av den generelle befolkningen får hypersensitivitetsreaksjoner ved bruk av et eller flere NSAID-preparater. Reaksjonene ses hyppigere hos dem med astma og kronisk idiopatisk urticaria (4). NSAID-preparater kan utløse alvorlige hypersensitivitetsreaksjoner som anafylaksi $(2,4)$. Klinikere bør tilegne seg tilstrekkelig kunnskap om mulige mekanismer, kliniske presentasjoner og riktig håndtering av slike hypersensitivitetsreaksjoner, spesielt med hensyn til valg av tryggere alternativer for pasienter med fremtidig behov for NSAID-midler.

I artikkelen gjennomgår jeg mulige mekanismer og kliniske karakteristika ved hypersensitivitetsreaksjoner forårsaket av NSAIDpreparater, og gir råd om håndtering av slike reaksjoner.

Grunnlaget for artikkelen er et litteratursøk i PubMed med søkeordene «hypersensitivity» og «non steroidal antiinflammatory drugs»». Det ble gjort et skjønnsmessig utvalg av artikler basert på min bakgrunn innen farmakologi og kliniske erfaring med legemiddelhypersensitivitet.

\section{Farmakologiske aspekter}

Ikke-steroide antiinflammatoriske legemidler hemmer cyklooksygenase-enzymene COX-1 og COX-2, som er nødvendig for dannelsen av prostaglandiner, prostasyklin og tromboksan A2 fra arakidonsyre. Hemming av COX1 forklarer flere av midlenes bivirkninger, særlig risiko for magesår og gastrointestinale blødninger. Isoenzymet COX-2 er induserbart og oppreguleres ved inflammasjon. Hemming av dette enzymet er en viktig forklaring på antiinflammatoriske og analgetiske effekter av NSAID-midler (5).

Selektivitet for COX-enzymene og grad av hemming varierer mellom de ulike preparatene (tab 1). Tradisjonelle NSAID-preparater hemmer både COX-1 og COX-2 (ikke-selektive COX-hemmere). Acetylsalisylsyre gir i motsetning til de andre NSAID-preparatene irreversibel hemming av COX-1 og hemmer i lave doser plateaggregeringen (6). Meloksikam og nimesulid hemmer COX-2 i større grad enn COX-1 (fortrinnsvise COX-2-hemmere) (7). Koksiber (selektive COX-2-hemmere) utgjør en nyere gruppe NSAID-preparater som ikke hemmer COX-1 i terapeutiske doser $(5,6)$. Paracetamol er en svak cyklooksygenasehemmer, men klassifiseres ikke som et NSAIDpreparat på grunn av manglende antiinflammatorisk effekt $(6,8)$. Cyklooksygenasehemmere utgjør en heterogen gruppe legemidler med ulike kjemiske strukturer. Ibuprofen, naproksen og ketoprofen er propionsyrederivater mens diklofenak, sulindak og ketorolak klassifiseres under eddiksyrederivater. Oksikamer (piroksikam og meloksikam), nabumeton, acetylsalisylsyre og paracetamol hører til fire ulike kjemiske grupper (8). Koksiber utgjør en egen strukturell gruppe.

\section{Klinisk klassifisering og mulige mekanismer}

Både immunologiske og ikke-immunologiske mekanismer antas å være involvert i NSAIDhypersensitivitet. På bakgrunn av ulike kliniske karakteristika og resultater av relevante kliniske studier er tre mulige mekanismer foreslått $(4,9)$ :

Hemming av COX-1 med påfølgende shunting av arakidonsyremetabolisme mot en alternativ metabolismevei (5-lipooksygenaseveien) er antatt å være en mulig farmakologisk mekanisme hos noen pasienter (fig 1). Dette medfører økt danning av cysteinylleukotriener som er potente mediatorer av inflammasjon, bronkospasme og ødem (5). Overproduksjon av cysteinylleukotriener er i kliniske studier bekreftet ved bruk av ulike laboratorieundersøkelser (4). Hypersensitivitetsreaksjoner er imidlertid rapportert ved bruk av selektive COX-2hemmere. Det foreligger i tillegg rapporter om kryssreaksjoner mellom koksiber og tradisjonelle NSAID-preparater, noe som antyder at også hemming av COX-2 kan være assosiert med NSAID-hypersensitivitet via foreløpig ukjente mekanismer (5).

IgE-mediert mekanisme (immunologisk straksreaksjon av type I) er en mulig mekanisme når kun en enkelt type NSAID-preparat er mistenkt som årsak til reaksjonen. Disse reaksjonene antas å være mediert av legemiddelspesifikke IgE-antistoffer og kan forsøkes dokumentert ved hjelp av hudprikktest. NSAID-spesifikke IgE-antistoffer er foreløpig ikke identifisert (med unntak av IgE-antistoff mot pyrazolon) $(4,9,10)$.

T-cellemediert mekanisme (immunologisk reaksjon av type IV) antas å være årsak til reaksjoner av forsinket type hvor legemiddelspesifikke cytotoksiske T-celler er involvert og kan forsøksvis avdekkes ved epikutantesting $(4,9)$.

Avhengig av tidsrelasjon mellom legemiddeleksponering og symptomdebut er hypersensitivitetsreaksjonene klassifisert som akutte (oppstår innen minutter eller få timer etter inntak) eller forsinkede (oppstår senere enn 24 timer etter inntak). De forsinkede reaksjonene kan variere fra milde eksantematøse utslett til alvorlige reaksjoner som Stevens-Johnsons syndrom (SJS), toksisk epidermal nekrolyse (TEN), DRESS-syndrom (drug rash with eosinophilia and systemic symptoms) eller organspesifikke

\section{Hovedbudskap}

- Hypersensitivitetsreaksjoner på NSAIDpreparater kan skyldes farmakologiske eller immunologiske mekanismer

- Diagnose og behandling varierer, avhengig av antatt mekanisme og kliniske karakteristika

- Provokasjonstest er det viktigste verktøyet i utredningen

- Utredningen bør avklare trygge alternativer og hvilke NSAID-preparater som bør unngås 
Tabell 1 Klassifisering av registrerte NSAID-preparater i Norge basert på grad av COX-hemming og selektivitet for COX-isoenzymene

\begin{tabular}{ll}
\hline COX-hemming & Legemidler \\
\hline Irreversible COX-1-hemmere & Acetylsalisylsyre \\
\hline Ikke-selektive COX-hemmere & $\begin{array}{l}\text { Piroksikam, sulindak, ibuprofen, naproksen, } \\
\text { ketoprofen, diklofenak, ketorolac, nabumeton }\end{array}$ \\
\hline Fortrinnsvise COX-2-hemmere & Meloksikam \\
\hline Selektive COX-2-hemmere & Celekoksib, etorikoksib, parekoksib \\
Svake COX-hemmere & Paracetamol \\
\hline
\end{tabular}

reaksjoner som hepatitt og nefritt. Akutte reaksjoner er ytterligere klassifisert $\mathrm{i}$ fire kategorier $(9,10)$ (fig 2).

\section{Utredning og praktisk håndtering}

Diagnostikk ved NSAID-hypersensitivitet er hovedsakelig basert på en grundig anamnese og en kontrollert administrering av mistenkte eller alternative legemidler (provokasjonstest) for å evaluere toleranse eller intoleranse $(11,12)$. Hudprikktest eller epikutantest (lappetest) kan utføres poliklinisk av legespesialister med kompetanse innen allergologi eller dermatologi ved mistanke om henholdsvis
IgE-medierte straksreaksjoner eller forsinkede hudreaksjoner. Prosedyrene ved slik testing er imidlertid ikke standardisert, og sensitivitet og spesifisitet for disse testene er variabel $(4,9,10)$. Testene kan benyttes som supplement til utredningen dersom praktiske forhold for å utføre disse er til stede.

En peroral placebokontrollert, enkeltblind provokasjonstest er det viktigste diagnostiske verktøyet ved utredning av NSAID-hypersensitivitet $(4,9,13)$. Testen innebærer peroral administrering av henholdsvis placebo og det mistenkte legemidlet på to påfølgende dager, hvor innholdet av tablettene er blindet for pasienten. Provokasjonstest bør først utføres med en lavere dose av det utvalgte NSAID-preparatet. Dersom det ikke tilkommer reaksjon, fortsetter man provokasjonstesten med administrering av full terapeutisk dose (13). Provokasjonstestprotokollen tilrettelegges etter det kliniske bildet og reaksjonstypen og vil variere med hensyn til administrasjonsrute, dose, observasjonstid, placebokontrollering og kriterier for evaluering $(9,10)$. Hos for eksempel pasienter med NSAID-utløst respirasjonssykdom (aspirin exacerbated respiratory disease - AERD), er peroral provokasjonstest med acetylsalisylsyre i gradvis økende doser og under jevnlige kontroller med spirometriske parametere den anbefalte diagnostiske protokollen (9).

Tidligere alvorlige reaksjoner på NSAIDpreparater som Stevens-Johnsons syndrom, toksisk epidermal nekrolyse, DRESS-syndrom (drug rash with eosinophilia and systemic symptoms) og affeksjon av organsystemer utgjør absolutte kontraindikasjoner for provokasjonstesting. Dersom det foreligger andre relative kontraindikasjoner, som alvorlig astma, hjerte- og karsykdom, organsvikt eller en tidligere mistenkt anafylaktisk reaksjon med NSAID-midler, bør man gjøre en grundig

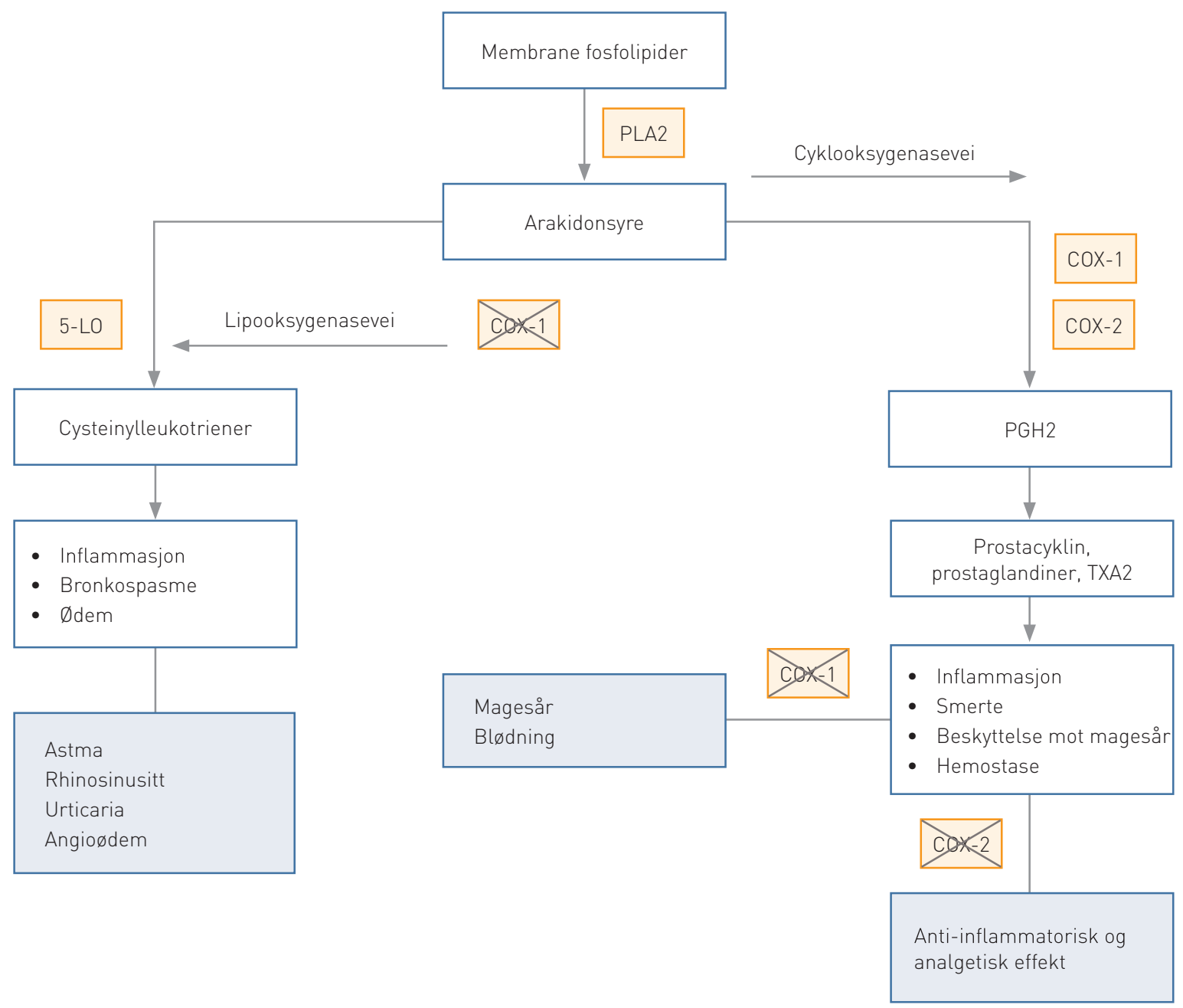

Figur 1 Metabolismeveier avarakidonsyre. Hypersensitivitetsreaksjoner på ikke-steroide antiinflammatoriske legemidler kan bl.a. skyldes hemming av isoenzymet COX-1 i cyklooksygenaseveien med shunting til lipooksygenaseveien. PLA2 = fosfolipase A2, 5-LO = 5-lipooksygenase, COX-1 =cyklooksygenase-1, COX-2 = cyklooksygenase $-2, P G H 2=$ prostaglandin $H 2$, TXA2 = tromboksan A2 


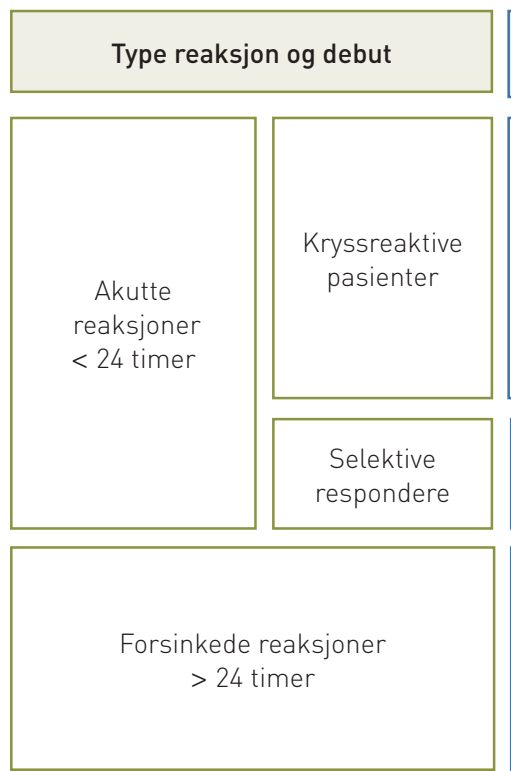

Kliniske kjennetegn
\begin{tabular}{|l|}
\hline 1. AERD hos pasienter med astma, nasale polypper og \\
rhinosinusitt
\end{tabular}
$\begin{aligned} & \text { 2. AECD hos pasienter med underliggende kronisk urticaria } \\
& \text { 3. Urticaria/angioødem indusert av flere ulike NSAID- } \\
& \text { preparater hos pasienter uten underliggende tilstander } \\
& \text { ved } 1 \text { og } 2\end{aligned}$
$\begin{aligned} & \text { 4. Urticaria/angioødem/anafylaksi indusert av } \\
& \text { ett enkelt NSAID-preparat }\end{aligned}$
$\begin{aligned} & \text { - Milde hudreaksjoner: makulopapuløst utslett } \\
& \text { - Alvorlige reaksjoner: Stevens-Johnsons syndrom og } \\
& \text { toksisk epidermal nekrolyse, DRESS-syndrom }\end{aligned}$
- Organspesifikke reaksjoner:hepatitt, nefritt

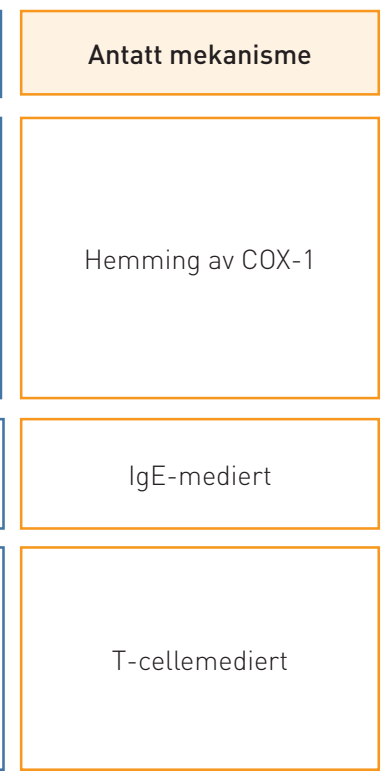

Figur 2 Type reaksjoner og antatte mekanismer ved NSAID-hypersensitivitet. AERD = aspirin exacerbated respiratory disease, AECD = aspirin exacerbated cutaneus disease, $C O X-1$ = cyklooksygenase-1, NSAID = ikke-steroide antiinflammatoriske midler, DRESS = drug rash with eosinophilia and systemic symptoms

nytte-risiko-vurdering om hvorvidt en provokasjonstest skal utføres eller ikke $(4,9)$.

Alle pasienter med mistanke om NSAIDutløste hypersensitivitetsreaksjoner bør vurderes for provokasjonstest. Avgjørelse om og gjennomføring av egnede provokasjonsprotokoller er en spesialistoppgave. Per i dag er Seksjon for klinisk spesialallergologi ved Haukeland universitetssykehus det eneste spesialiserte medisinske senteret som utfører denne testen i Norge, men testen kan også utføres av trente legespesialister ved andre medisinske sentre under akuttberedskap. Klinikere som bruker NSAID-preparater i behandlingen, bør kjenne til mulige mekanismer og kliniske kjennetegn ved NSAID-hypersensitivitet. Pasientene bør få skriftlig informasjon om hvilke typer preparater de skal unngå. Alternativt valg av NSAID-middel bør være basert på negativ provokasjonstest med disse preparatene.

Kryssreaktive pasienter, pasienter i kategori 1-3 (fig 2), som har hatt to eller flere reaksjoner på minst to strukturulike NSAIDpreparater, må unngå de mistenkte preparatene og andre NSAID-preparater med lik eller større evne til å hemme COX-1. Svake COX-1-hemmere som paracetamol (i doser lavere enn $1000 \mathrm{mg}$ som enkeltdose) og fortrinnsvise eller selektive COX-2-hemmere (tab 1), kan forsøkes som alternative legemidler hos denne pasientgruppen. Negativ provokasjonstest med disse alternative legemidlene $\mathrm{i}$ forkant av forsøket vil øke tryggheten av valget $(9,10)$.

Selektive respondere, pasienter i kategori 4 (fig 2), som har hatt en akutt reaksjon på et enkelt NSAID-preparat, skal unngå alle NSAIDpreparater som hører til samme kjemisk gruppe. Disse pasientene bør generelt ikke provoseres med det mistenkte NSAID-preparatet (9, 10). Dersom reaksjonen ikke har hatt en alvorlig eller livstruende karakter, og det foreligger en sterk indikasjon for videre behandling med det aktuelle NSAID-preparatet, kan provokasjonstest likevel vurderes utført. Det samme gjelder for forsinkede reaksjoner av mildere karakter. Ved alvorligere forsinkede reaksjoner er derimot provokasjonstest kontraindisert. Ved anamnese om alvorlige akutte reaksjoner (som anafylaksi) og eventuelt en positiv hudtest med det mistenkte NSAID-preparatet er det anbefalt at provokasjonstest utføres med NSAID-preparater tilhørende strukturulike grupper - for å utelukke kryssreaktivitet og dokumentere toleranse til disse alternative NSAID-midlene $(4,9,10)$.

\section{Konklusjon}

NSAID-preparater er en hyppig årsak til hypersensitivitetsreaksjoner på legemidler. Kunnskap om underliggende mekanismer og kliniske karakteristika ved hypersensitivitet kan bidra til riktigere håndtering av slike reaksjoner. Ved anamnestisk mistanke om en hypersensitivitetsreaksjon på NSAID-preparater er provokasjonstest med mistenkte og/ eller alternative legemidler det viktigste verktøyet både for å bekrefte eller avkrefte tilstanden og for å finne tryggere alternativer. Utredning og testing kan utføres ved Seksjon for klinisk spesialallergologi ved Haukeland universitetssykehus. Alternativt kan testen utføres ved andre medisinske sentre med anafylaksiberedskap, eventuelt i samråd med spesialister ved Haukeland universitetssykehus.

Jeg takker Erik Florvaag, Aud Berstad, Bettina Riedel og Jan Schjøtt for verdifull veiledning.

\section{Fatemeh Chalabinloo (f. 1969)}

er spesialist i klinisk farmakologi og overlege. Forfatteren har fylt ut ICMJE-skjema og oppgir ingen interessekonflikter.
Litteratur

1. Pichler WJ. Drug hypersensitivity reactions: Classification and relationship to T-cell activation. I: Pichler WJ, red. Drug Hypersensitivity. Basel: Karger, 2007: 168-189.

2. Cornejo-Garcia JA, Blanca-López N, Doña I et al. Hypersensitivity reactions to non-steroidal antiinflammatory drugs. Curr Drug Metab 2009; 10: 971-80.

3. Chalabianloo F, Berstad A, Schjøtt J et al. Clinical characteristics of patients with drug hypersensitivity in Norway: a single-centre study. Pharmacoepidemiol Drug Saf 2011; 20: 506-13.

4. Sánchez-Borges M, Caballero-Fonseca F, Capriles-Hulett A et al. Hypersensitivity reactions to nonsteroidal anti-inflammatory drugs: an update. Pharmaceuticals 2010; 3: 10-8.

5. Sánchez-Borges M, Capriles-Hulett A, CaballeroFonseca F. Cutaneous reactions to aspirin and nonsteroidal antiinflammatory drugs. Clin Rev Allergy Immunol 2003; 24: 125-36. . Review.

6. Norsk Legemiddelhåndbok. Ikke-steroide antiinflammatoriske midler. www.legemiddelhandboka.no (12.6.2011).

7. Woessner KM Simon RA, Stevenson DD. The safety of celecoxib in patients with aspirin-sensitive asthma. Arthritis Rheum 2002; 46: 2201-6.

8. Sánchez-Borges M. Clinical management of nonsteroidal anti-inflammatory drug hypersensitivity. World Allergy Organization Journal 2008; 1: 29-33.

9. Kowalski ML, Makowska JS, Blanca M et al. Hypersensitivity to nonsteroidal anti-inflammatory drugs (NSAIDs) - classification, diagnosis and management: review of the EAACI/ENDA(\#) and GA2LEN/HANNA. Allergy 2011; 66: 818-29.

10. Romano A, Torres MJ, Castells M et al. Diagnosis and management of drug hypersensitivity reactions. J Allergy Clin Immunol 2011; 127 (suppl): S67-73.

11. Sánchez-Borges M, Capriles-Hulett A, CaballeroFonseca F. NSAID-induced urticaria and angioedema: a reappraisal of its clinical management. Am J Clin Dermatol 2002; 3: 599-607.

12. Semik A, Barczyk A, Pierzcha?a W. Provocation tests in the diagnosis of acetylsalicylic acid intolerance. Wiad Lek 2005; 58: 543-8.

13. Nizankowska-Mogilnicka E, Bochenek G, Mastalerz $L$ et al. EAACI/GA2LEN guideline: aspirin provocation tests for diagnosis of aspirin hypersensitivity. Allergy 2007; 62: 1111-8

Mottatt 1.8. 2011, første revisjon innsendt 5.1. 2012, godkjent 21.6. 2012. Medisinsk redaktør Mette Sagsveen/Kristin Viste. 